\title{
Interthalamic adhesion in humans: a gray commissure?
}

\author{
Jorge Eduardo Duque Parra ${ }^{1,2}$, Álex Pava Ripoll ${ }^{1,2}$, Juan Fernando Vélez García ${ }^{3}$ \\ ${ }^{1}$ Department of Basic Sciences, Faculty of Health Sciences, Universidad de Caldas, Manizales, ${ }^{2}$ Medicine Program, Department of Basic Sciences, \\ Universidad de Manizales, Manizales, ${ }^{3}$ Department of Animal Health, Faculty of Veterinary Medicine and Zootechnics, Universidad del Tolima, \\ Ibagué, Colombia
}

\begin{abstract}
Interthalamic adhesion is an inconstant part of the human diencephalic neuroanatomy, which some histological studies have indicated it is a gray commissure and others a white commissure. Its presence has been associated with alterations in health status, including schizophrenia, psychotic states, and hydrocephalus. Thirty-one fresh human brains were evaluated randomly, to determine the presence of interthalamic adhesion and its histological composition, by way of lamina terminalis puncture of the third ventricle. Photographic records were taken and histological processes was performed by hematoxylin-eosin staining, in the case of the existence of the adhesion. It was found that $51.71 \%$ did present interthalamic adhesion, and on histological examination, no neuron bodies were found in the median part, which implies that does not correspond to a gray commissure, but interthalamic adhesion in humans is variable, with a predominance of glial cells. There is no gray commissure in human interthalamic adhesions.
\end{abstract}

Key words: Anatomy, Diencephalon, Histology, Neuroanatomy, Thalamus

Received August 13, 2021; Revised September 10, 2021; Accepted September 13, 2021

\section{Introduction}

Interthalamic adhesion, or intermediate mass [1-5], may be inconsistently identified in the diencephalon [4, 6-8], as it is located horizontally on the median line [9] and formed by the fusion of the median border of both thalami [10]. Histologically, it is an adhesion of nervous tissue, an element that crosses the third ventricle [11]. It was discovered by Italian anatomist Giovanni Battista Morgagni (1682-1771), who called the interthalamic gray lamina union lamina transversa cinerea [4]. It is formed by neurons and commissural fibers, which develop during the fetal period and following birth [12]. Connections are made with the anterior frontal

\section{Corresponding author:}

Juan Fernando Vélez García (i)

Department of Animal Health, Faculty of Veterinary Medicine and Zootechnics, Universidad del Tolima, Ibagué 730006299, Colombia E-mail: jfvelezg@ut.edu.co cortex by way of this adhesion [13], although their function is unknown [14]. Jacques Benigne Winslow (1669-1760) considered this adhesion to be a white matter union [15] which corresponds to axons and thalamic oligodendrocytes, which are present in varying degrees. The presence of this adhesion has recorded diverse percentages: $80 \%$ of healthy subjects [4], between $63 \%$ and $83 \%$ [14], 70\%-80\% [15], 70\%-80\% [16], 70\% [17], 33\% in healthy individuals [11], and between $33 \%$ in males and $25 \%$ in females [17]. Although its presentation is irregular, may occur doubly, in certain cases [17]. Both thalami can be totally fused, but only in cases of brain dysmorphias, such as occurs in holoprosencephaly [18]. Interthalamic adhesion is little related in neuroimaging [19], but there are studies of magnetic resonance, that it extends further in males than in females [20]. In postmortem studies, it has been found that, between $15 \%$ and $30 \%$ of cases, the structure never develops, as a variation of normality [21]. It may swell throughout various illness processes, a fact which was made evident in the postmortem studies of individu-

\section{Copyright (c) 2022. Anatomy \& Cell Biology}

This is an Open Access article distributed under the terms of the Creative Commons Attribution Non-Commercial License (http://creativecommons.org/licenses/by-nc/4.0/) which permits unrestricted non-commercial use, distribution, and reproduction in any medium, provided the original work is properly cited. 


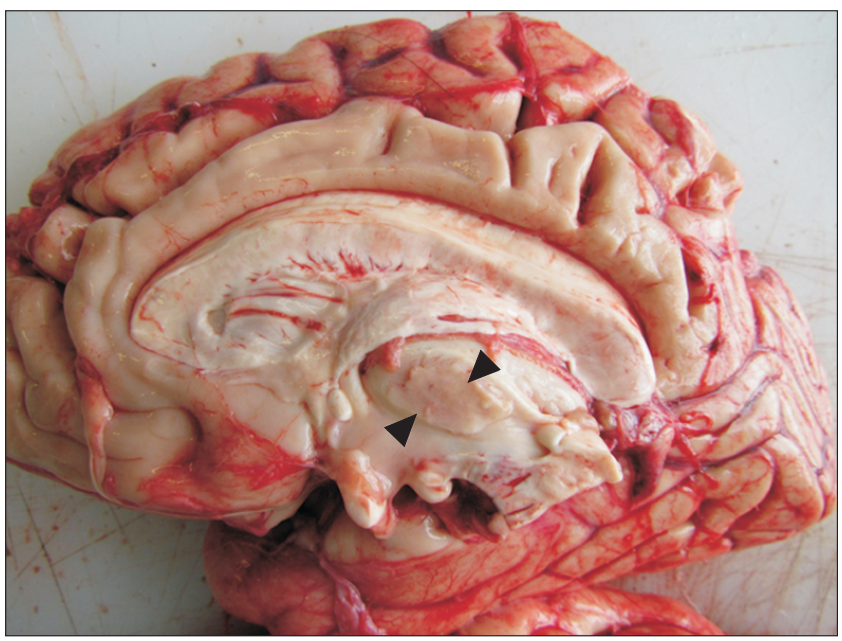

Fig. 1. Medial view of a median section of an encephalon (diencephalon), with a great interthalamic adhesion (black triangles) inferior to the choroid plexus of the third ventricle.

als who suffered from schizophrenia [22], additionally, its absence was more common than controls [23]. In the case of its presentation in individuals with schizophrenia, its absence is more prevalent in male than in female patients [24], and there may be possible correlations between its absence in psychotic states [25]. Further, it has been postulated that interthalamic adhesion may influence patron patterns and cerebrospinal fluid on the cerebral ventricles, and have functional implications for the development of hydrocephalus [26]. Opposite the state of alteration in individuals with illness, it has been correlated to their IQs [9]. The objective of the present work was to analyze in inter-thalamic adhesions the presence of a commissure between adjacent thalamus.

\section{Materials and Methods}

Thirty-one fresh brains, from senior cadavers, were dissected, without consideration of sex or ethnicity. The materials utilized were obtained based strictly on the legal medical criteria contained in Colombian Decree 786 of 1990. All principles contained in the Helsinki declaration for medical research were followed, so as to ensure respect for the body parts obtained for the investigation, as well as the confidentiality of the data of the deceased, their dignity, and honest treatment. Inclusion criteria was as follows: not having died from brain trauma, non-presentation of malformations or macroscopic tumor processes which might affect the morphology of the area to be studied, and that they not be the fruit of morphological alterations, owing to the manipulation

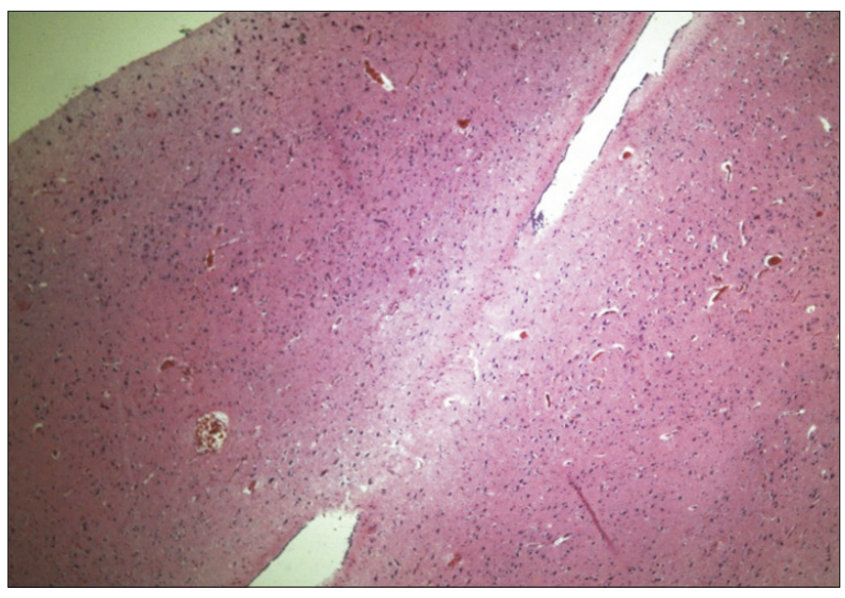

Fig. 2. Histological view of a horizontal section of the interthalamic adhesion $($ zoom $\times 4$ ) between right and left thalamus in hematoxylin and eosin stain.

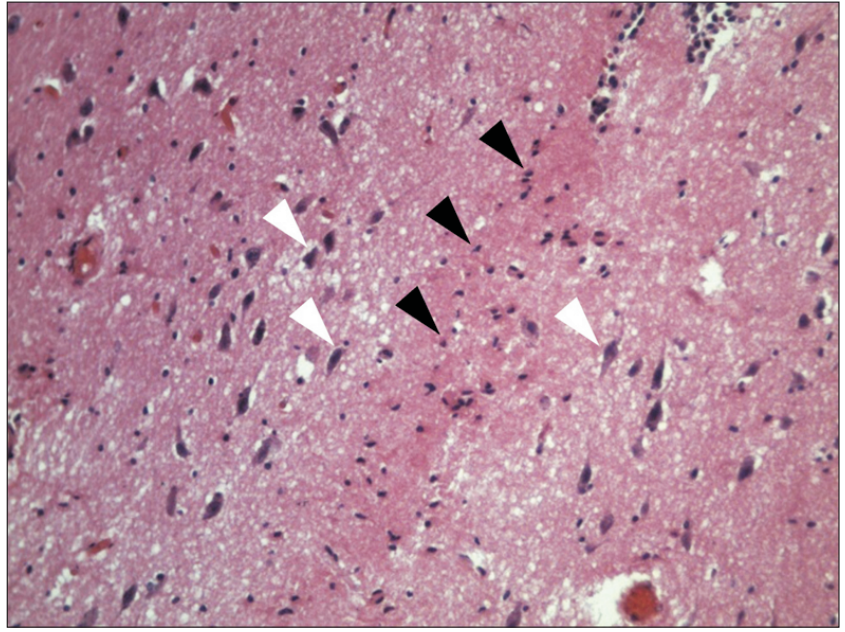

Fig. 3. Histological view of a horizontal section of the interthalamic adhesion (zoom $\times 20)$, in which the absence of gray commissure it is notable, but glial cells are distinguished (black triangles), and laterally, soma of pyramidal neurons (white triangles), with anterior to posterior soma orientation in hematoxylin and eosin stain.

which followed extraction from the cadaver. The specimens were targeted at the anterior basal region, on the terminal lamina level in the diencephalon, so as to inspect the interior of the third ventricle, and it was retired and histologically processed by hematoxylin-eosin stain, for the evaluation of nerve cells and white matter bridges.

\section{Results}

In 31 brains evaluated, it was found in gross neuroanatomy that $15(48.4 \%)$ presented interthalamic adhesion (Fig. 1). 
The histological study did not find the presence of gray commissure, although certain glial cells, and pyramidal neurons lateral to these, whose soma were oriented longitudinally from posterior to anterior, did demonstrate presence (Figs. 2, 3).

\section{Discussion}

Interthalamic adhesion has received little attention in the literature [21], although variable percentages thereof are recognized, estimated between $25.0 \%$ and $86.7 \%$ [3, 4, 11, 16, $17,27,28]$, including a value of $48.4 \%$ reported in the present study, which indicates great variable of this diencephalic adhesion. Although this is considered a gray commissure [29], its presentation is controversial, emerging from its first descriptor who called interthalamic gray lamina [15] and a term maintained by some $[4,5]$. In gray commissures, neuronal somas must prevail, which was not found in the present investigation, as neural somas were found laterally, and were oriented toward the anterior posterior axis, opposite the direction of the adhesion. This aspect is congruent with indications that the majority of thalamic neurons do not send axons to the contralateral thalamus [11]. This denotes axonal commissure, but not somas; instead, it is performed by a connecting axon bridge $[11,12,30]$. Although its function is unknown [9], as white commissure must transmit action potentials, given that the neurons transport their signals by way of axons [31] between the thalamus, which connects their corresponding median parts [11], perhaps by way of axons, which, following an anterior posterior course, curve toward the contralateral side, or by way of collaterals. Interthalamic adhesion may include glial cell bridges, as shown in this investigation, and perhaps involves the oligodendrocytes that surround axons.

In conclusion, we found no neuronal cell bodies in 15 interthalamic adhesions and conclude that the interthalamic adhesion is not likely to be a gray commissure.

\section{ORCID}

Jorge Eduardo Duque Parra:

https://orcid.org/0000-0002-1432-6381

Álex Pava Ripoll: https://orcid.org/0000-0001-6119-6623

Juan Fernando Vélez García:

https://orcid.org/0000-0003-1517-2916

\section{Author Contributions}

Conceptualization: JEDP, APR. Data acquisition: JEDP, APR. Data analysis or interpretation: JEDP, APR, JFVG. Drafting of the manuscript: JEDP, APR, JFVG. Critical revision of the manuscript: JEDP, APR, JFVG. Approval of the final version of the manuscript: all authors.

\section{Conflicts of Interest}

No potential conflict of interest relevant to this article was reported.

\section{References}

1. Federative Committee on Anatomical Terminology. Terminologia anatomica: international anatomical terminology. New York: Thieme; 1998. p. 120.

2. Lansdell H, Davie JC. Massa intermedia: possible relation to intelligence. Neuropsychologia 1972;10:207-10.

3. Malobabić S, Puskas L, Blagotić M. Size and position of the human adhaesio interthalamica. Gegenbaurs Morphol Jahrb 1987;133:175-80.

4. Trzesniak C, Kempton MJ, Busatto GF, de Oliveira IR, Galvãode Almeida A, Kambeitz J, Ferrari MC, Filho AS, Chagas MH, Zuardi AW, Hallak JE, McGuire PK, Crippa JA. Adhesio interthalamica alterations in schizophrenia spectrum disorders: a systematic review and meta-analysis. Prog Neuropsychopharmacol Biol Psychiatry 2011;35:877-86.

5. Tubbs RS, Smyth MD, Oakes WJ, Blount JP. Duplication of the massa intermedia in a child. Pediatr Neurosurg 2004;40:42-3.

6. Vélez García JF, Pedraza Ordoñez FJ, Duque Parra JE. [La adhesión intertalámica del bovino: un estudio piloto]. Rev Med Risaralda 2013;19:30-1. Spanish.

7. Duque A, Roa E, Castedo J. [White matter anatomy using tensor diffusion tractography]. Radiologia 2008;50:99-111. Spanish.

8. Satheesha Nayak B, Soumya KV. Unusually large interthalamic adhesion and its clinical importance. Int J Anat Var 2010;3:1745.

9. Gibbons A. The brain as "sexual organ". Science 1991;253:957-9.

10. Zawitsch C. [Kommissuren und andere Fasersysteme in einer Massa intermedia Thalami des Menschen]. Wien Z Nervenheilkd Grenzgeb 1952;4:74-93. German.

11. Whitehead MT. Thalamic massa intermedia duplication in a dysmorphic 14 month-old toddler. J Radiol Case Rep 2015;9:15.

12. Firbas W, Volavsek C. [Ontogenesis of adhaesio interthalamica (massa intermedia) in man]. Anat Anz 1970;126:205-10. German.

13. Cholvin T, Loureiro M, Cassel R, Cosquer B, Geiger K, De 
Sa Nogueira D, Raingard H, Robelin L, Kelche C, Pereira de Vasconcelos A, Cassel JC. The ventral midline thalamus contributes to strategy shifting in a memory task requiring both prefrontal cortical and hippocampal functions. J Neurosci 2013;33:8772-83.

14. Damle NR, Ikuta T, John M, Peters BD, DeRosse P, Malhotra AK, Szeszko PR. Relationship among interthalamic adhesion size, thalamic anatomy and neuropsychological functions in healthy volunteers. Brain Struct Funct 2017;222:2183-92.

15. Olry R, Haines DE. Interthalamic adhesion: scruples about calling a spade a spade? J Hist Neurosci 2005;14:116-8.

16. Kochanski RB, Dawe R, Kocak M, Sani S. Identification of stria medullaris fibers in the massa intermedia using diffusion tensor imaging. World Neurosurg 2018;112:e497-504.

17. Rabl R. [Studies on the structure of the massa intermedia of the thalamus opticus]. J Hirnforsch 1958;4:78-112. German.

18. Ciftcioglu E, Ozyurek H, Nural MS, Kopuz C, Incesu L, Ogur G. Absence of the lateral and third ventricles associated with holoprosencephaly. Anat Cell Biol 2015;48:222-4.

19. Duque Parra JE, Marín Arias F, Duque Vera IL. Interthalamic adhesion: an approach from basic science to implement clinic neuroimaging. Paper presented at: 3rd European Conference on Clinical Neuroimaging; 2014 Mar 31-Apr 1; Lille, France. p. 27-8.

20. Mohammadi MR, Hosseini SH, Golalipour MJ. Morphometric measurements of the thalamus and interthalamic adhesion by MRI in the South-East of the Caspian Sea border. Neurosciences (Riyadh) 2008;13:272-5.

21. Laslo P, Slobodan M, Nela P, Milos M, Rade P, Tatjana I. Specific circular organization of the neurons of human interthalamic adhesion and of periventricular thalamic region. Int J Neurosci 2005;115:669-79.

22. Agarwal N, Rambaldelli G, Perlini C, Dusi N, Kitis O, Bellani
M, Cerini R, Isola M, Versace A, Balestrieri M, Gasparini A, Mucelli RP, Tansella M, Brambilla P. Microstructural thalamic changes in schizophrenia: a combined anatomic and diffusion weighted magnetic resonance imaging study. J Psychiatry Neurosci 2008;33:440-8.

23. Haghir H, Mokhber N, Azarpazhooh MR, Haghighi MB, Radmard M. A magnetic resonance imaging study of adhesio interthalamica in clinical subtypes of schizophrenia. Indian J Psychiatry 2013;55:135-9.

24. de Souza Crippa JA, Zuardi AW, Busatto GF, Sanches RF, Santos AC, Araújo D, Amaro E, Hallak JE, Ng V, McGuire PK. Cavum septum pellucidum and adhesio interthalamica in schizophrenia: an MRI study. Eur Psychiatry 2006;21:291-9.

25. Takahashi T, Yücel M, Yung AR, Wood SJ, Phillips LJ, Berger GE, Ang A, Soulsby B, McGorry PD, Suzuki M, Velakoulis D, Pantelis C. Adhesio interthalamica in individuals at high-risk for developing psychosis and patients with psychotic disorders. Prog Neuropsychopharmacol Biol Psychiatry 2008;32:1708-14.

26. Cheng S, Tan K, Bilston LE. The effects of the interthalamic adhesion position on cerebrospinal fluid dynamics in the cerebral ventricles. J Biomech 2010;43:579-82.

27. Samra KA, Cooper IS. Radiology of the massa intermedia. Radiology 1968;91:1124-8.

28. Dauber W, Feneis H. Pocket atlas of human anatomy. 5th ed. New York: Thieme; 2007. p. 360.

29. Park KA, Lee HY, Chung IH, Han YP, Shin TS. A morphologic study of interthalamic adhesions in Korean brains. Clin Anat 1993;6:33-6.

30. Sullivan EV, Rosenbloom M, Serventi KL, Pfefferbaum A. Effects of age and sex on volumes of the thalamus, pons, and cortex. Neurobiol Aging 2004;25:185-92.

31. Paulus W. [Los efectos de la estimulación transcraneal]. Mente Cereb 2016;76:46-53. Spanish. 